\title{
ENGLISH LEARNING MOTIVATION AND SPEAKING ABILITY
}

\author{
Menggo, S. \\ STKIP Santu Paulus, Ruteng, Indonesia
}

\section{A R T I C LE IN F O \\ Article history: \\ Received 19 April 2016 \\ Received in revised form 6 October 2016 \\ Accepted 12 October 2016 \\ Available online 20 October 2016}

\section{Keywords:}

English Learning,

Learning Motivation,

Speaking Ability

\begin{abstract}
A B S T R A C T
The aim of communicative language teaching is enable learners to communicate in the target language. A learner is sued to perform the micro and macro components in each utterance produced. Consequently, students need to know the linguistics forms, meanings and functions of that target language. They need to know that many different forms can be used to perform a function and also that single form can often serve a variety of functions. Students must be able to choose from among these the most appropriate form, given the social context and manage the process of negotiating meaning with their interlocutors. However, knowing learner's English learning motivation is an urgent variable to be considered in creating conducive atmosphere classroom which will raise the learners to do more toward speaking achievement. The aim of this study is to know and describe the English learning motivation affecting students' speaking ability of 48 students of XI grade of science program at catholic senior of Saint Ignasius Loyola Labuan Bajo, West Flores, Indonesia. Correlation design with purposive procedure applied in this research. Data were collected through questionnaire, interview, and students' speaking document. Result shows that motivation is significantly affecting students' speaking ability.
\end{abstract}

\section{Introduction}

This study examines the correlation between English learning motivation and speaking ability toward 48 students of XI grade of science program of senior high schools at Saint Ignasius Loyola Labuan Bajo, West Flores, Indonesia. Motivation has a vital role in leading learners' achievement. It also has a formidable task for language learners. Thus motivation is used as a 'effective tool' in considering the failure or success of a learner. Dörnyei (1998) claimed that motivation is a key factor in learning including English speaking. It is an inner source, preference, desire, emotion, reason, need, impulse or purpose that moves a person to a particular action. Motivation is regarded as one of the prime factors that influence the speed and amount of success of foreign language learners. Genc \& Aydin (2017) reported that motivation is of the most important components affecting language acquisition. It's contributed to learners' attitudes and it should be kept in mind in the learning process

Kitjaroonchai \& Kitjaroonchai (2012) found out that there is a significant positive relation between students' learning motivation and their academic achievement. Motivation as a 'smart processor' to facilitate learners' need, increases students' learning outcomes and obtain the purpose of the school's curriculum. It also helps learners to determine what they have stored at their mind, what they can do, and then what skill they need to learn in the target language. Chalak \& Kassaian (2010) also revealed a positive correlation between motivation (instrumental and integrative) and of their English learning achievement. Then Kitjaroonchai (2012) claimed that students who had high motivation (integrative and Instrumental) would help them felt with bright future career, education opportunity, and communication in the rapid change of globalization.

Although previous researches present convincing evidence that motivation as a key factor in learning and it has positive relation between students' learning motivation and their English achievement (Al-Qahtani, 2013; Long, Ming, \& Chen, 2013; Hong \& Ganapathy, 2017), the concept of English learning 
motivation to do more toward speaking ability for senior high school students has not been strongly supported by recent research findings.

While the assumption that English learning motivation influences speaking ability is commonly accepted. Motivation plays an extremely important role in study and high achievers have a strong sense of achievement (Li \& Pan, 2009; Piniel \& Csizér, 2013). In this paper, the concept of English learning motivation extremely influences toward students' speaking ability is highly supported.

Some studies have provided evidence that English learning motivation influences toward students' speaking ability. For example, Degang (2010) who claimed that students are relatively high English learning motivated, close to equally motivated to speak English. Huang (2010) also reported that student's self-confidence and intrinsic motivation as significantly factors affecting students' English speaking frequencies outside the classroom. Moreover, Tuan \& Mai (2015) disclosed that English speaking motivation is believed as one of the factors affecting the students' speaking performance. Then Ghanbarpour (2016) reported that one's motive facilitates to communicate toward interlocutor. It is deemed to be essential to learners' language learning success.

\subsection{English Learning Motivation}

Understanding students' English learning motivation has a very important role to make students gain success in learning English. It is an urgent variable to be considered by teacher in recognizing the students' problem and to create conducive atmosphere in the classroom that will raise the students to do more toward learning English. By having the great motivation, the learners are able to respond to the learning situation, seek out all opportunities to acquire English language, make maximum use of the opportunities afforded to practice the language, possess analytic skill, be adaptable in learning situation possess, self-esteem, and take a risk for their learning. Thus, undoubtedly the most frequently used catch all term for explaining the success or failure of virtually any complex task, motivation is a star player in the cast of characters assigned to learning English scenarios around the world. Schunk, Pintrich, \& Meece (2008) defined motivation as 'basis motor' to achieve some goals. Motivation provokes a decision to act.

Uno (2009) affirmed the roles of motivation in learning, such as motivation can determine learning reinforcement, motivation makes learning objectives clearer and motivation makes learning persistent. Further, Astuti (2012) reported that motivation is psychology factor that can influence the process and the result of learning. If the students have high learning motivation, they students will do more learning activity. So, it is suggested that the teacher must improve students' English learning motivation. As teachers, they often forget that all of their learning activities are filtered through their students' motivation. In this sense, students control the flow of the classroom. Without student's motivation, there is no pulse; there is no life in the class. When teachers learn to incorporate direct approaches to generating student motivation in their teaching, they will become happier and more successful teachers. Thus motivation contributes to successful of second language acquisition (Anjomshoa \& Sadighi, 2015).

Motivation is examined as a factor of a number of different kinds of attitudes. Two different clusters of attitudes divided two basic types of the orientation of motivation (Brown, 2007). These two different basic types of the orientation of motivation are instrumental and integrative. Instrumental refers to acquiring a language as a means for attaining instrumental goals, such as furthering a career, reading technical material, achievement, translation, and so forth. Then integrative means learners who wish to integrate themselves into the culture of the target language group and become involved in social interchange in that group. In line with Brown's insight, Gardner (1985) also divided two types of learner's motivation in language learning, such as integrative motivation and instrumental motivation. Both types of these motivations affect the success of second language acquisition from different perspectives.

English teachers may be strongly argued that the most powerful dimension of the whole motivation construct in general is the degree to which learners are intrinsically or extrinsically motivated to successes in English task (Brown, 2007). According to him intrinsically motivated activities are ones for which there is no apparent reward expect the activity itself. People seem to engage in the activities for their own sake and not because they lead of an extrinsic reward. Intrinsically motivated behaviors are aimed at bringing about certain internally rewarding consequences, namely, feelings of competence and self-determination. Whereas extrinsic motivation is fueled by the anticipation of a reward from outside and beyond the self. These two types of motivation have different effect toward students' success in learning a language. Intrinsic motivation is more powerful than extrinsic motivation because of intrinsic motivation potentially creates excellence, autonomy and self-actualization. However, the differences of these motivational dichotomies can be described to the following table 1: 
Table 1.

The differences of motivational dichotomies

\begin{tabular}{lll}
\hline Type & Intrinsic motivation & Extrinsic motivation \\
\hline Integrative & $\begin{array}{l}\text { Learner wishes to integrate with the } \\
\text { L2 or target language culture (e.g., for } \\
\text { immigration or marriage) }\end{array}$ & $\begin{array}{l}\text { Someone else wishes the L2 learner to know } \\
\text { the L2 for integrative reasons (e.g., Japanese } \\
\text { parents send kids to Japanese language } \\
\text { school) }\end{array}$ \\
$\begin{array}{ll}\text { Instrumental } \\
\text { Learner wishes to achieve goals } \\
\text { utilizing L2 or target language (e.g., for } \\
\text { a career or study achievement) }\end{array}$ & $\begin{array}{l}\text { (e.g., corporation sends Japanese businessman } \\
\text { to U.S. for language training) }\end{array}$ \\
\hline
\end{tabular}

\subsection{Speaking Ability}

Strong English speaking ability supports communication skill achievement. Speaking is viewed as a skill in conveying information, ideas or concepts to the interlocutor (Atkinson, 1985). Accordingly speaker is sued to delivery thought clearly, accurately and acceptably. Mastery of language is not only determined by how many or large the mastery of grammar but also how accurate and clear the speaker says the words, phrases, or sentence by sentence in the speech of information; states the ideas in complete sentences. Main ideas are the most important information to be conveyed by the speaker; develop ideas by providing explanations, descriptions or examples; use sentences which are easy to be understood by interlocutors; and use the appropriate sentences intonation and gestures (body movements or eye contact) is to help interlocutor's understanding. In line with that, Lazaraton (2001) defined speaking as an activity requiring the integration of many subsystems of language. All these subsystems should be combined by a speaker to make speaking a second or foreign language a formidable task for language learners. Subsystems which meant by Lazaraton including linguistic competence which is meant as the knowledge of the language code (phonology, morphology, syntax and semantics); discourse competence which highlights to the knowledge of how to produce oral texts in the modes of speaking respectively; sociolinguistic competence where the knowledge of sociocultural rules of use, i.e. knowing how to use and respond to language appropriately. The appropriateness depends on the setting of the communication, the topic, and the relationships among the people communicating. Moreover, being appropriate depends on knowing what the taboos of the other culture are, what politeness are used in each case, what the politically correct term would be for something, how a specific attitude (authority, friendliness, courtesy, irony etc.) is expressed, etc; and (4) strategic competence is the ability to recognise and repair communication breakdowns before, during, or after they occur. For instance, the speaker may not know a certain word, thus will plan to either paraphrase, or ask what that word is in the target language. During the conversation, background noise or other factors may hinder communication; thus the speaker must know how to keep the communication channel open. If the communication was unsuccessful due to external factors (such as interruptions), or due to the message being misunderstood, the speaker must know how to restore communication. These strategies may be requests for repetition, clarification, slower speech, or the usage of gestures, taking turns in conversation, etc. Burnkart (1998) highlighted speaking dimension which help learners to be able to speak clearly, accurately and acceptably. Those dimensions involve three areas of knowledge. The first is mechanic (pronunciation, grammar, and vocabulary). The learners are expected to use the right words in the right order with the correct pronunciation. The second is functions (transaction and interaction). The learners are expected to know the clarify of message. The third is social and cultural norms (turn-taking, rate of speech, length of pauses between speakers, relatives roles of participants). The learners are expected to understand how to take into account, who is speaking to whom, in what circumstances, about what and for what reasons.

Then Thornbury (2005) defined speaking is much more complex and involves certain skills and several types of knowledge. Linguistic and non-linguistic knowledge should be performed equally by a speaker. More than that Brown (2004) defined speaking is so much a part of daily life; a speaker is sued to be able to show their micro skills (linguistic competence) and macro skills (linguistic performance) as prime basis in speaking activity.

Fromkin (2003) said that micro and macro components as basis for a speaker in supporting communicative competence. Micro components (linguistic competence), how speaker's knowledge of their language is performed in the particular interaction, such as lexicon production; morphology; syntax; semantics; and the phonetics and phonology. Macro components (performance competence), how speaker's knowledge of language interacts with non-linguistic knowledge, namely pragmatic and sociolinguistic competences. Freeman (2003) highlights micro and macro components of communicative competence in terms of language teaching. By having sufficient communicative competence understanding enable learners use the target language. To do this, students need to know micro and 
macro components that are knowledge of the linguistic forms, meanings, and functions. Students need to know that many different forms can be used to perform a function and also that a single form can often serve a variety of functions. Learners must be able to choose from among these the most appropriate form, given the social context and the roles of the interlocutors. They must be able to manage the process of negotiating meaning with their interlocutors. In this paper, English speaking ability indicated by the ability of students to perform speaking dimension as has been statedby Burnkart above.

Reference to the aforementioned literature reviews, it is obvious that the correlation between English learning motivation and speaking ability is very essential to be understood by senior high school students and their English teachers.

\section{Methods}

This was a correlation research and involved 48 students of XI grade of science program of senior high schools at Saint Ignasius Loyola Labuan Bajo, West Flores, Indonesia on March 2017. Purposive procedure was used in this research. Data collected through questionnaire, interview, and students' speaking document. Then data were analyzed by using person product moment.

\section{Findings and Discussion}

Research hypothesis relevant with the correlation between English learning motivation and students' speaking ability. Researcher found out that there was significant correlation between English learning motivation and students' speaking ability. This result referenced to the value of coefficient correlation $\left(r_{x, y}: 0,8\right.$ then $\mathrm{t}_{\mathrm{ob}}: 9,04$ and $\left.\mathrm{t}_{\mathrm{cv}}: 2,0105\right)$. Since $\mathrm{t}_{\text {observation }}$ was higher than $\mathrm{t}_{\text {critical value }}\left(\mathrm{t}_{\mathrm{ob}}>\mathrm{t}_{\mathrm{cv}}\right)$ which means that there is significant correlation

From the hypothesis testing of this study, it was found out that there was significant correlation between English learning motivation and students' speaking ability. This research finding is in line with relevant concepts and previous relevant researches which both highlighted that motivation is psychology factor that significantly contribute toward students' speaking performance. There are two types of motivation, namely; instrumental and integrative (Krashen (1988). Respondents' English learning motivation was assessed by five dimensions of instrumental motivation namely; achieving goal, anticipating failure, having orientation toward the challenge and competition, having high responsibility toward the assignment, and having opinion toward function of English learning in their study. Each dimension has clear bearing toward indicator stated. Then, this questionnaire was analyzed in determining high and low students' English learning motivation.

Interview result also indicates that students' motive in speaking English caused by intrinsic and extrinsic motivation. Intrinsic motivation refers to student him/herself, such as lack of self confidence and lack of motivation which could make students feel ashamed to speak, scared to make mistakes, and have no confidence. In fact, it has a very important role to make students gain success in speaking English. Meanwhile, extrinsic motivation is the outside factors which related with the teacher (professional and persistence), school support, appropriate curriculum, sufficient teaching resources, efficient assessment instruments, English speaking environment support, time allocation, etc. The teacher should be able to recognize these problems to create conducive atmosphere in the classroom that will raise the students' ability to speak English. Harmer (2007) categorized intrinsic and extrinsic motivation in different perspective. Intrinsic motivation is 'kind of motivation that is generated by what happens inside the classroom; teacher's method, the activities students take part in, or their own perception of success or failure'. Meanwhile extrinsic motivation is 'kind of motivation which comes from outside the classroom or external factors, such as the attitude of society, family and peers'. These two types influence toward learning' speaking achievement. Lucas, et al (2010) revealed that motivation is an important factor in learning a second and foreign language. Motivation is defined as the individual's attitudes, desires, and effort. It is as positive energy and practical direction for all aspects of activation in supporting learning achievement. Someone is motivated for engaging in the relevant activities, expends effort, persists in the activities, attends to the tasks, shows desire to achieve the goal, enjoys the activities, and the like obviously cannot be separated by their English learning motivation.

Moreover, speaking ability is defined as the ability of a speaker to speak language naturally and subconsciously. Speakers may express their idea through verbal and non-verbal symbols in their communication. Then communication takes place, of course, there is a speaker and listener. The goal of communicative language teaching is to enable students to communicate in the target language. Consequently, students need to know the linguistics forms, meanings and functions of that target language. They need to know that many different forms can be used to perform a function and also that 
single form can often serve a variety of functions. Students must be able to choose from among these the most appropriate form, given the social context and manage the process of negotiating meaning with their interlocutors in that target language. Related to enable students to communicate, speaking skill must be a major focus in the teaching learning activities (Kayi, 2006; Celce-Murcia, 2001).

Speaking is productive skill which focuses an active process of negotiating meaning and using micro and macro components toward utterances produced. Speaking has differ strategies depend on the purpose of the interaction. Interaction falls into two broad categories; transactional and interactional. Transactional situations usually involve people in interactions where speakers wish to obtain information or goods and services. Meanwhile, interactional situation usually involve speakers in casual conversations where the main purpose is to establish or maintain social contact with other people. These two categories can be achieved through how to elaborate competence and performance (Burns and Joyce, 1999). The ability to speak a language is synonymous with knowing that language since speech is the most basic means of human communication.

\section{Conclusion}

There is significant correlation between English learning motivation and students' speaking ability at Saint Ignasius Loyola Labuan Bajo senior high school. This result reflects to EFL teachers and learners that psychology factor (motivation) contributes toward students' cognitive and performance domain. EFL teachers not only focus on cognitive and performance factors in the English instruction but also students' psychology factor. These are inter-depended. This inter-dependency as a top direction for EFL teacher in assessing students' speaking achievement holistically.

\section{References}

Al-Tamimi, A., and Shuib, M. (2009). Motivation and attitudes towards learning English: A study of petroleum engineering undergraduates at Hadhramout university of sciences and technology. GEMA online journal of language studies, 9 (2), 29-55.

Al-Qahtani, M, F. (2013). Relationship between English language, learning strategies, attitudes, motivation, and students' academic achievement. Education in medicine journal, 5 (3), 19-29. DOI: 10.5959/eimj.v5i3.124.

Anjomshoa,L., \& Sadighi, F. (2015). The importance of motivation in second language acquisition. International Journal on Studies in English Language and Literature, 3 (2), 126-137.

Astiti, S, N. (2012). The effect of cooperative learning strategy (Jigsaw II technique) and achievement motivation on the speaking achievement of the tenth grade students of SMKN 3 Singaraja (Thesis). Singaraja: Universitas Pendidikan Ganesha Singaraja.

Atkinson, R. H., \& Longman, D. G. (1985). Reading enhancement and development. New York: West Publishing Company.

Brown, D, H. (2004). Language assessment: Principles and classroom practices. New York: Addison Wesly Longman Inc.

Brown, D. H. (2007). Principles of language learning and teaching (fifth edition). San Fransisco: Pearson Education, Inc.

Burnkart, G. S. (1998). Spoken language: What it is and how to teach it. Washington: Center for Applied Linguistics.

Burns, A \& Joyce,H. (1999). Focus on Speaking. Sydney: Macquarie University.

Chalak, A \& Kassaian, Z. (2010). Motivation and attitudes of Iranian undergraduate EFL students towards learning English. GEMA online journal of language studies, 10 (2), p.37-56.

Celce-Murcia, M. (2001). Teaching English as a Second or Foreign Language (Third Edition). USA: Heinle \& Heinle Thomson Learning, Inc. 
Chiu-Ping Huang, Chiu-Ping. (2010). Exploring factors affecting the use of oral communication strategies (research publication). Lunghwa: Lunghwa University of Science and Technology.

Chomsky, N. (1965). Aspects of the theory of syntax (p.10). Cambridge: MIT Press.

Degang, M. (2010). Motivation toward English language learning of the second year undergraduate Thai students majoring in business English at an English-medium university (thesis). Srinakharinwirot: Srinakharinwirot University.

Dörnyei, Z. (1998). Motivation in second and foreign language learning. Language Teaching, 31, 117-35.

Gardner, R. C. (1985) Social psychology and second language learning: The role of attitudes and motivation. London: Edward Arnold.

Fromkin, V. A. (2003). Linguistics: An introduction to linguistic theory. Oxford: Blackwell Publishing Ltd.

Genc, z, s., \& Aydin, F. (2017). An analysis of learners' motivation and attitudes toward learning English language at tertiary level in Turkish EFL context. English language teaching journal, 10 (4), 35-44. DOI: $10.5539 /$ elt.v10n4p35.

Ghanbarpour, M. (2016).Willingness to communicate, linguistic self-confidence, and language-use anxiety: the Iranian EFLcontext. Theory and practice in language studies, 6 (12), 2265-2271. DOI: http://dx.doi.org/10.17507/tpls.0612.05.

Harmer, J. (2007). How to (new edition). England: Pearson Longman.

Hong, Y, C., \& Ganapathy, M. (2017). To investigate ESL students' instrumental and integrative motivation towards English language learning in a Chinese school in Penang: Case study. English language teaching journal, 10 (9), 17-35. DOI: 10.5539/elt.v10n9p17.

Hymes, D. (1972). On communicative competence. In Pride, J.B.; Holmes, J. Sociolinguistics: selected readings (p. 269-293). Harmondsworth: Penguin.

Kayi, H. (2006). Teaching Activities: Activities to Promote Speaking in a Second Language. Retrieved July 26, 2018, from https://www.scribd.com/document/251204059/Teaching-Speaking-Activities to promote in a second language.

Kitjaroonchai, N., \& Kitjaroonchai, T. (2012). Motivation toward English language learning of Thai students majoring in English at Asia-pacific international university. Catalyst journal, 7 (1),21- 38.

Kitjaroonchai, N. (2012). Motivation toward English language learning of students in secondary and high schools in education service area office 4, Saraburi province, Thailand. International journal of language and linguistics, 1 (1), 22-33. DOI: 10.11648/j.ijll.20130101.14.

Krashen, S. (1988). Second language acquisition and second language learning. London: Prentice Hall International (UK).

Larsen-Freeman, D. (2003). Techniques and principles in language teaching (second edition). Oxford: Oxford University Press.

Lazaraton, A. (2001). Teaching oral skills. In: Celce-Mulcia, M (eds) Teaching English as a second or foreign language (third edition). New York: Heinle\&Heinle, Ltd.

Li, P \& Pan, G. (2009). The relationship between motivation and achievement: a survey of the study motivation of English majors in Qingdao agricultural university. English language teaching, 2 (1), 123-128. 
Long, C., Ming, Z., \& Chen, L. (2013). The study of student motivation on English learning in junior middle school: A case study of no.5 middle school in Gejiu. English language teaching, 6 (9), 136145. DOI: $10.5539 /$ elt.v6n9p136.

Lucas, et al. (2010). A study on the intrinsic motivation factors in second language learning among selected freshman students. Philippine ESL journal, 4, 3-23.

Piniel, K., \& Csizér, K. (2013). L2 motivation, anxiety and self-efficacy: the interrelationship of individual variables in the secondary school context. Studies in second language learning and teaching, 3 (4), 523-550.

Schunk, D, H., Pintrich, P, R., Meece, J, L. (2008). Motivation in education: theory, research, and applications (third edition). New Jersey: Pearson Education, Inc.

Thornburry, S. (2005). How to teach speaking. England: Pearson Educated Limited.

Tuan, N, H \& Mai, T,N. (2015). Factors affecting students' speaking performance at Le Thanh Hien high school. Asian journal of educational research, 3 (2) 8-23.

Uno, H, B. (2009). Teori motivasi \& pengukurannya: Analisi di bidang pendidikan. Jakarta: Bumi Aksara. 